\title{
Pengaruh Lama Penyimpanan terhadap Aktivitas Antioksidan Berbagai Macam Jus Buah Berdasarkan Metode DPPH
}

\author{
Budiman Hartono ${ }^{1}$, Chrisanto², Inggrid Osya Farfar¹ \\ ${ }^{1}$ Departemen Biologi, Fakultas Kedokteran dan Ilmu Kesehatan Universitas Krida Wacana \\ ${ }^{2}$ Fakutas Kedokteran dan Ilmu Kesehatan Kristen Krida Wacana \\ Alamat korespondensi: budimanhrtn@yahoo.com
}

\begin{abstract}
Abstrak
Saat ini banyak upaya untuk mengkonsumsi jus buah untuk khasiat antioksidan. Antioksidan merupakan senyawa yang mampu menghambat atau mencegah kerusakan akibat oksidasi dari senyawa radikal bebas. Radikal bebas yang terlalu banyak dapat menyebabkan stres oksidatif sel. Jus buah yang dijual umum seringkali disimpan dalam jangka waktu yang lama sebelum dikonsumsi. Penelitian ini dilakukan untuk mengetahui bagaimana pengaruh lama penyimpanan terhadap aktivitas antioksidan dalam empat macam jus buah. Pada penelitian kali ini empat macam buah yang digunakan, yaitu: stroberi, jeruk, pisang dan alpukat. Radikal bebas yang biasa digunakan pada sampel pada penelitian antioksidan adalah 1,1-difenil-2pikrilhidrazil (DPPH). Parameter untuk menginterpretasikan hasil pengujian DPPH adalah konsentrasi inhibisi/inhibition concentration $\left(\mathrm{IC}_{50}\right.$ ). Hasil penelitian menunjukkan $\mathrm{IC}_{50}$ buah stroberi sebesar $31,45 \mathrm{ppm}$, $\mathrm{IC}_{50}$ buah jeruk sebesar 58,01 ppm, $\mathrm{IC}_{50}$ buah alpukat sebesar 78,83 ppm dan $\mathrm{IC}_{50}$ buah pisang sebesar 92.99 ppm. Penelitian ini menggunakan analisis statistik One-Way Anova dan mendapatkan hasil p=0,992, dikarenakan $\mathrm{p}>0,05$ maka hasil ini menunjukkan tidak ada perbedaan yang bermakna antara lama penyimpanan terhadap nilai $\mathrm{IC}_{50}$ dari hari ke-1 sampai ke-4. Dapat disimpulkan bahwa lama waktu penyimpanan hingga hari keempat tidak berpengaruh secara bermakna terhadap nilai $\mathrm{IC}_{50}$ jus buah-buah tersebut.
\end{abstract}

Kata kunci: radikal bebas, antioksidan, $\mathrm{IC}_{50}, 1,1$-difenil-2-pikrilhidrazil (DPPH)

\section{The Effect of Storage Time on Antioxidant Activities of Various Fruit Juices According to DPPH Method}

\begin{abstract}
Nowadays, there is ample efforts to consume fruit juices to reap the benefits of its antioxidants. Antioxidants are compounds that can inhibit or prevent oxidation damage from free radical compounds. Excessive free radicals can cause oxidative stress to cells. Fruit juices for sale are often consumed after a long period in storage. This research was conducted to find out how storage time affects antioxidant properties in four kinds of fruit juices. The fruits examined in this study were: strawberries, oranges, bananas and avocados. The free radical commonly used in samples of antioxidant research is1.1-difenyl-2-Pikrilhidrazil (DPPH). The Parameter to interpret the DPPH test result is inhibition concentration $\left(I C_{50}\right)$. The results showed an $I C_{50}$ of $31.45 \mathrm{ppm}$ for strawberries, $58.01 \mathrm{ppm}$ for oranges, $78.83 \mathrm{ppm}$ for avocados and $92.99 \mathrm{ppm}$ for bananas. The study used One-Way Anova resulting in $p=0.0992$, at a significance of $p>0.05$, which means there was no meaningful difference between the length of storage against the value of IC $C_{50}$ from Day 1 to 4. It can be concluded that length of storage up to four days has no meaningful effect on the $I C_{50}$ value for these fruit juices.
\end{abstract}

Keywords: free radicals, antioxidants, IC $C_{50}$ 1,1-difenil-2-pikrilhidrazil (DPPH) 


\section{Pendahuluan}

Di dalam dunia kesehatan sering dibahas tentang radikal bebas dan antioksidan. Di zaman sekarang ini banyak bahan radikal bebas yang terdapat pada tubuh seseorang disebabkan karena radikal bebas banyak ditemukan di lingkungan sekitarnya seperti polusi udara akibat asap rokok, knalpot kendaraan, polusi air akibat pembuangan limbah yang sembarangan, makanan instan, penggunaan pestisida yang berlebihan pada sayur-sayuran dan buah-buahan. ${ }^{1}$

Radikal bebas adalah suatu senyawa oksigen yang bersifat tidak stabil karena memliki elektron bebas yang tidak berpasangan, sehingga jumlah elektronnya ganjil. Karena sifatnya yang tidak stabil maka radikal bebas selalu berusaha mencari pasangan elektron baru dengan cara mengambil elektron molekul lain yang berdekatan. ${ }^{1}$ Radikal bebas yang terlalu banyak pada tubuh dapat menyebabkan stress oksidatif sel, sehingga terjadi ketidakseimbangan antara radikal bebas dengan antioksidan alami dalam tubuh. ${ }^{2,3}$

Antioksidan merupakan senyawa yang mampu menghambat atau mencegah kerusakan akibat oksidasi dari senyawa radikal bebas. Tubuh dapat menciptakan antioksidan alami seperti enzim gluthatione, catalase dan superoxydedismutase. Antioksidan alami juga dapat ditemukan dari alam seperti vitamin A, vitamin $\mathrm{C}$ dan vitamin E. ${ }^{4}$ Antioksidan dibagi menjadi dua yaitu, antioksidan alami dan sintetik. Contoh antioksidan sintetik yaitu Butil Hidroksi Toluen (BHT) dan Butil Hidroksi Anisol (BHA). ${ }^{4}$ Namun, penggunaan antioksidan sintetik mulai dibatasi karena bersifat karsinogenik dan beracun terhadap hewan percobaan. ${ }^{5}$

Jus buah Penelitian terhadap kandungan vitamin $\mathrm{C}$ cabai merah (Capsicum annum L.) menunjukkan bahwa lama penyimpanan sembilan hari berpengaruh terhadap aktivitas antioksidan. ${ }^{6}$ Penelitian terhadap buah stroberi juga mendapatkan hasil yang sama, bahwa penyimpanan selama 14 hari juga berpengaruh terhadap aktivitas antioksidan. ${ }^{7}$ Pada penelitian yang dilakukan Galani dkk pada tahun 2017, penyimpanan sayur dan buah-buahan dalam pendingin selama 29 hari ditemukan meningkatkan asam phenolat namun menurunkan phenolat total, anthocyanis dan vitamin $\mathrm{C}$, yang mengakibatkan hilangnya kapasitas antioksidan. ${ }^{8}$ Oleh karena itu dilakukan penelitian ini untuk mengetahui adakah pengaruh lama penyimpanan terhadap empat macam jus buah. Empat macam jus buah yang digunakan pada penelitian kali ini yaitu ; buah stroberi, buah jeruk manis, buah pisang cavendish, dan buah alpukat mentega.

Radikal bebas yang biasa digunakan pada sampel pada penelitian antioksidan adalah 1,1difenil-2-pikrilhidrazil (DPPH). Penelitian menunjukkan bahwa metode DPPH mudah dan memiliki tingkat keakuratan yang tinggi untuk mengukur aktivitas antioksidan pada buah dan sayur-sayuran. ${ }^{9}$

Dalam penelitian kali ini, digunakan empat macam jus buah sebagai sumber antioksidan alami karena antioksidan alami jauh lebih aman. Biasanya tidak ada efek negatif dari bahan tersebut yang dapat mengganggu kesehatan manusia. Pada penelitian ini digunakan empat macam buah yaitu buah stroberi (Fragaria $x$ ananassa), jeruk manis (Citrus sinensis), pisang cavendish (Musa cavendish) dan alpukat mentega (Persea americana). Buah-buahan tersebut dipilih karena buah-buahan tersebut sering dikonsumsi, buahnya mudah didapat dan harganya masih terjangkau. Kemudian, diantara keempat jus buah tersebut akan dibandingkan jus buah yang mana memiliki efek antioksidan yang lebih tinggi dan mengetahui pengaruh lama penyimpanan terhadap aktivitas antioksidan.

\section{Metodologi Penelitian}

\section{Desain Penelitian}

Desain penelitian ini merupakan penelitian ini merupakan penelitian eksperimental laboratorik untuk mengetahui pengaruh aktivitas antioksidan berbagai macam jus buah dengan metode DPPH

\section{Subjek Penelitian}

Subjek penelitian yang digunakan adalah jus buah stroberi (Fragaria $x$ ananassa), jeruk manis (Citrus sinensis), pisang cavendish (Musa cavendish) dan alpukat mentega (Persea americana). 


\section{Bahan dan Alat}

Bahan penelitian adalah etanol, DPPH, BHT, buah alpukat, buah stroberi buah jeruk, bauah pisang. Alat yang digunakan adalah sentrifus, blender, vortex dan Spektrofotometer Uv-Vis.

\section{Pengolahan Sampel}

Tiap buah ditimbang sebanyak 100 gram kemudian di blender hingga halus. Setiap buah kemudian disaring dengan menggunakan kertas saring. Kemudian hasil saringan setiap empat buah tersebut di sentrifuse dengan kecepatan 5000 rpm selama 20 menitlalu di pisahkan antara cairan jus buah dengan ampas yang mengendap dibawahnya dengan menggunakan pipet. Kemudian timbang ke 4 cairan jus buah dengan berat masing-masing $100 \mathrm{mg}$ dan dilarutkan dengan $100 \mathrm{ml}$ etanol. Sehingga dihasilkan konsentrasi dengan 1000 ppm. Tutup wadah dengan menggunkan alumunium foil dan disimpan di dalam lemari es dengan suhu $4^{\circ} \mathrm{C}$.

\section{Pembuatan Larutan DPPH}

Serbuk DPPH (BM 394,32) ditimbang dengan berat 19,7 mg. Masukkan DPPH ke dalam labu ukur dan dilarutkan dengan $500 \mathrm{ml}$ etanol. Tutup labu ukur menggunakan alumunium foil kemudian aduk DPPH hingga homogen. Dari hasil tersebut akan didapatkan DPPH dengan konsentrasi $0,1 \mathrm{mM}$.

\section{Pengukuran Aktivitas Antioksidan BHT}

Timbang BHT dengan berat $100 \mathrm{mg}$ kemudian larutkan dengan $100 \mathrm{ml}$ etanol sehingga didapatkan konsentrasi sebesar 1000 ppm. Dari larutan tersebut diambil sebanyak 20 ppm, 30 ppm, 40 ppm dan 50 ppm. Kemudian ditambah dengan $1 \mathrm{ml}$ larutan DPPH dan ditambah dengan metanol sampai $6 \mathrm{ml}$. Larutan tersebut kemudian dihomogenkan dan diinkubasi di ruangan gelap selama 30 menit dan dicek serapannya dengan panjang gelombang $517 \mathrm{~nm}$.

\section{Pengukuran Aktivitas Antioksidan Jus Buah}

Setiap jus buah diambil konsentrasi sebanyak 20 ppm, 30 ppm, 40 ppm dan 50 ppm. Untuk mendapatkan 20 ppm masukkan $2 \mathrm{ml}$ konsentrasi jus buah yang sudah dilarutkan dalam etanol. Pada penelitian kali ini digunakan perbandingan $10 \mathrm{ppm}$ karena dengan selisih 10 ppm sudah menunjukkan adanya perbedaan jumlah yang cukup signifikan. Tambahkan $1 \mathrm{ml}$ DPPH pada kelima konsentrasi jus buah dan ditambahkan dengan etanol hingga mencapai 6 $\mathrm{ml}$. Kemudian dihomogenkan dan diinkubasi selama 30 menit di ruangan gelap. Kemudian dicek serapannya dengan panjang gelombang 517 $\mathrm{nm}$. Lakukan pengulangan pengukuran setiap hari sampai hari keempat untuk melihat ada pengaruh lama penyimpanan atau tidak.

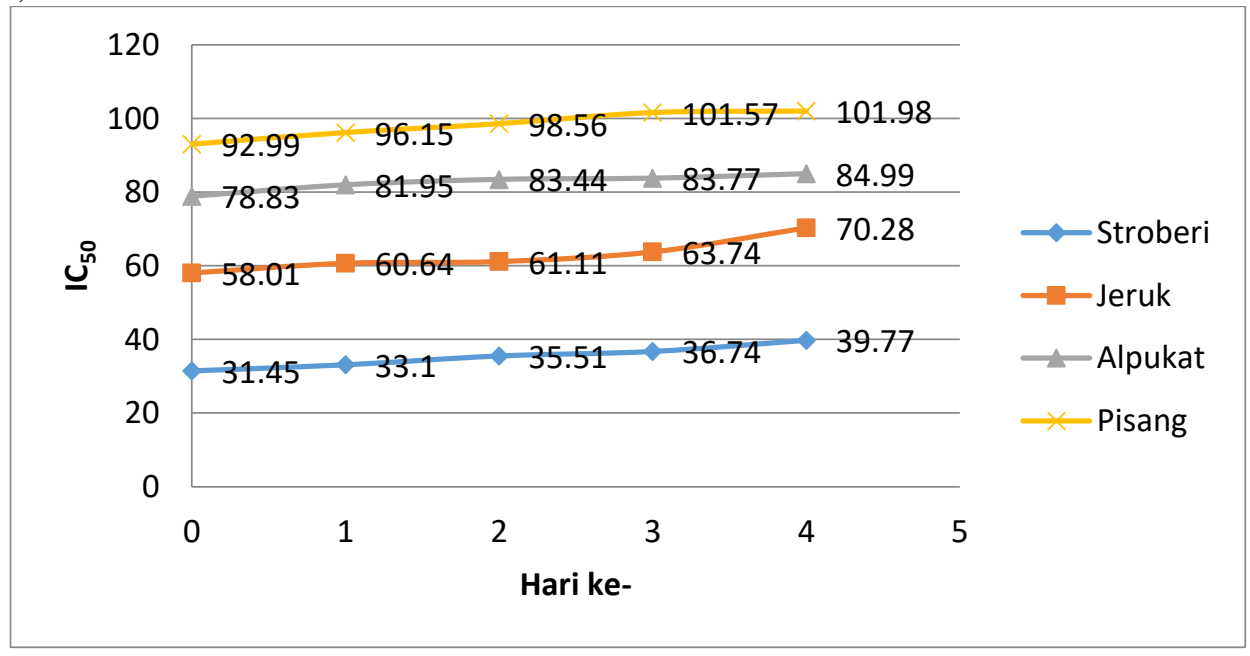

Gambar 1. Gambar Perbandingan Nilai IC 50 $_{0}$ Selama Penyimpanan 


\section{Hasil Penelitian dan Pembahasan}

Dari hasil absorbansi sampel akan didapatkan persentase penghambatan DPPH (\% inhibisi). Kemudian dapat ditentukan nilai inhibitory concentration $\left(\mathrm{IC}_{50}\right.$ ). Nilai $\mathrm{IC}_{50}$ adalah besarnya konsentrasi suatu senyawa yang dibutuhkan untuk menghambat 50\% dari DPPH. Untuk menghitung $\mathrm{IC}_{50}$ dapat digunakan persamaan regresi linear. ${ }^{10}$

Kontrol positif yang digunakan disini adalah BHT. BHT merupakan antioksidan sintetik yang sering digunakan pada makanan. BHT berbentuk kristal putih dan tidak beraroma. BHT merupakan senyawa yang tidak bisa larut di dalam air tetapi mudah larut dalam lemak dan etanol. Mekanisme kerja antioksidan BHT adalah menghambat reaksi oksidasi dengan menyumbangkan atom $\mathrm{H} .{ }^{11}$ Pada penelitian kali ini digunakan kontrol positif BHT dibandingkan BHA karena ada penelitian yang menunjukkan bahwa BHA memliki sifat yang toksik dan karsinogenik terhadap hewan. Oleh karena itu penggunaan BHT lebih sering digunakan sebagai kontrol positif. ${ }^{12}$

Pada Gambar 1 dapat dilihat bahwa buah yang memiliki tingkat antioksidan tertinggi adalah buah stroberi dengan nilai $\mathrm{IC}_{50}$ sebesar 31,45 ppm untuk mengikat DPPH dengan konsentrasi $0,1 \mathrm{mM}$. Selanjutnya ada buah jeruk dengan $\mathrm{IC}_{50} 58,01 \mathrm{ppm}$, buah alpukat dengan nilai $\mathrm{IC}_{50} 78,83 \mathrm{ppm}$ dan buah dengan antioksidan terendah adalah buah pisang dengan nilai $\mathrm{IC}_{50}$ sebesar 92,99 ppm. BHT merupakan kontrol positif yang sering digunakan pada makanan sebagai antioksidan sintetik.

Tabel 1 Tingkat Kekuatan Antioksidan ${ }^{13}$

\begin{tabular}{cc}
\hline $\begin{array}{c}\text { Intensitas } \\
\text { Antioksidan }\end{array}$ & $\begin{array}{c}\text { Nilai IC }_{\mathbf{5 0}} \\
\text { (PPM) }\end{array}$ \\
\hline Sangat Kuat & $<50$ \\
Kuat & $50-100$ \\
Sedang & $100-250$ \\
Lemah & $250-500$ \\
Tidak aktif & $>500$ \\
\hline
\end{tabular}

Pada Tabel 1 tampak bahwa stroberi masuk ke dalam golongan buah dengan tingkat antioksidan yang sangat kuat karena memiliki $\mathrm{IC}_{50}$ sebesar $31,45 \mathrm{ppm}$. Sedangkan buah jeruk masuk kedalam kategori buah dengan tingkat antioksidan yang kuat karena memiliki $\mathrm{IC}_{50}$ 78 sebesar 58,01 ppm. Buah alpukat dengan tingkat antioksidan kuat karena nilai $\mathrm{IC}_{50} 78,83 \mathrm{ppm}$. Buah pisang dengan tingkat antioksidan kuat karena nilai $\mathrm{IC}_{50} 92,99$ ppm.

Dari penelitian yang dilakukan oleh Santoso dkk pada tahun $2015, \mathrm{IC}_{50}$ buah stroberi adalah 20,6 ppm. $^{14}$ Penelitian terhadap buah pisang cavendish mendapatkan $\mathrm{IC}_{50}$ sebesar 232,08 ppm, ${ }^{15}$ sedangkan $\mathrm{IC}_{50}$ pada buah jeruk manis adalah 333,7 ppm. ${ }^{16}$ Pada penelitian yang dilakukan oleh Zahra pada tahun 2016, terhadap masker peel-off minyak daging buah alpukat (Persea Americana Mill), didapatkan hasi $\mathrm{IC}_{50}$ pada buah alpukat adalah 116.4 ppm. ${ }^{17}$ Adanya perbedaan pada penelitian ini kemungkinan disebabkan karena adanya perbedaan konsentrasi dari DPPH, teknik ekstraksi sampel dan perlakuan sampel.

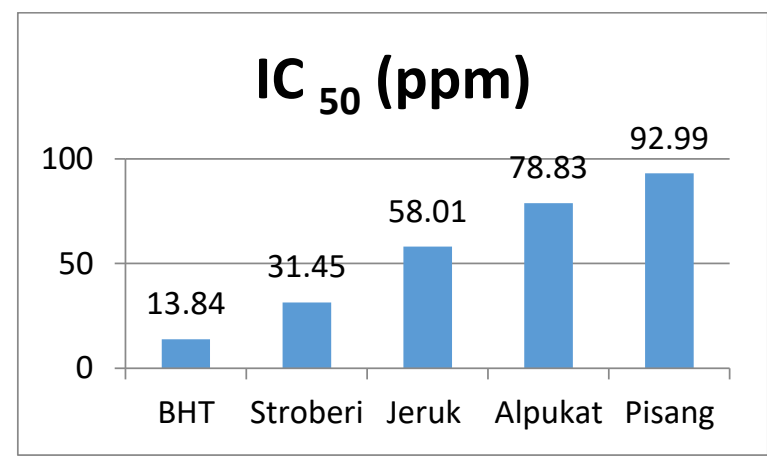

Gambar 2. Perbandingan Nilai IC 50 pada Berbagai Macam Jus Buah

Pada Gambar 2 terlihat bahwa pada keempat jus buah yang telah disimpan memiliki nilai $\mathrm{IC}_{50}$ yang terus meningkat seiring dengan lama waktu penyimpanan. Dari grafik tersebut juga dapat terlihat buah yang memiliki penurunan aktivitas antioksidan paling cepat adalah buah jeruk. Selanjutnya buah pisang, stroberi dan buah yang penurunannya paling lambat adalah alpukat. Kemudian untuk mengetahui apakah ada pengaruh yang bermakna antara lama penyimpanan terhadap nilai $\mathrm{IC}_{50}$ maka akan dilakukan analisis statistic dengan menggunakan program SPSS dengan metode One Way Anova.

Dari hasil SPSS One Way Anova didapatkan hasil $\mathrm{p}=0,992$. Hasil $\mathrm{p}>0,05$ menunjukkan bahwa tidak ada perbedaan yang bermakna dari nilai $\mathrm{IC}_{50}$ pada lama waktu penyimpanan dari hari ke-1 sampai ke-4. Hal ini 
menunjukkan bahwa lama waktu penyimpanan tidak berpengaruh secara bermakna terhadap nilai $\mathrm{IC}_{50}$ setiap buah. Pada penelitian yang dilakukan oleh Budiarti pada tahun 2015, ddidapatkan hasil aktivitas antioksidan (\% inhibisi) pada cabai merah (Capsicum annuum. L) sebesar 35,58\% dan terjadi penurunan pada hari ketujuh dengan nilai aktivitas antioksidan yang menjadi $16,85 \% .^{18}$ Menurut penelitian yang dilakukan oleh Ozruk dkk pada tahun 2017 terhadap Cherry Laurel (Prunus laurocerasus L.)" didapatkan penurunan hasil aktivitas antioksidan berdasarkan kandungan phenolatdari $\mu \mathrm{mol} / \mathrm{g} 43,54$ menjadi $30,58 \mu \mathrm{mol} / \mathrm{g}$ pada hari ke-21. ${ }^{19}$ Penelitian yang dilakukan oleh Tilahun dkk pada tahun 2016 terhadap tomat (Lycopersicon esculentum Mill., didapatkan hasil aktivitas antioksidan (\% inhibisi) sebesar $91,04 \%$ dan terjadi peningkatan pada hari ke-20 sebesar $91,4 \% .^{20}$

Hasil penelitian ini menunjukkan penurunan aktivitas antioksidan, namun hingga hari keempat, penurunan tidak bermakna secara statistik. Perbedaan hasil penelitian ini dengan penelitian kemungkinan dapat disebabkan oleh karena adanya perbedaan lama waktu penyimpanan, penggunaan etanol sebagai pelarut sehingga tidak mudah terjadi pembusukan, dan cara penyimpnan sampel karena pada penelitian ini sampel disimpan di dalam kulkas $4^{\circ} \mathrm{C}$ dan wadah sampel ditutup dengan alumunium foil.

\section{Simpulan}

Berdasarkan hasil penelitian ini, didapatkan bahwa buah yang memliki aktivitas antioksidan tertinggi adalah buah stroberi. Buah stroberi memiliki aktivitas antioksidan yang sangat kuat. Buah jeruk, pisang dan alpukat memiliki aktivitas antioksidan kuat. Namun, keempat jus buah tersebut belum memiliki aktivitas antioksidan sekuat BHT. Walaupun lama penyimpanan menurunkan kadar antioksidan setiap jus buah, hasil dari analisis statistik menunjukkan bahwa hingga hari keempat tidak ditemukan penurunan yang bermakna $(\mathrm{p}=0,992)$.

\section{Daftar Pustaka}

1. Agarwal S, Rao AV. Tomato lycopene and its role in human health and chronic diseases.
Canadian Medical Association Journal. 2010;163(6):739-44

2. Juniarti OD, Yuhernita. Kandungan senyawa kimia, uji toksisitas (BSLT) dan antioksidan (1,1-diphenyl-2-pikrilhydrazyl) dari ekstrak daun saga. Makara Sains. 2009;13:50-4.

3. Fahrunnida PR. Kandungan saponin buah, daun dan tangkai daun belimbing wuluh (Averrhoa bilimbi L.). Prosiding Seminar Nasional Konservai dan Pemanfaatan Sumder Daya Alam. FKIP UNS. 2015;1(1):220-24.

4. Martinus BA, Verawati. Penentuan kadar flavonoid total dan aktivitas antioksidan dari ekstrak daun bandotan (Ageratum conyzoides L.). Scientia. 2015;5(1):47-52.

5. Adegoke GO, Falade, AT. Effect of Aframomum danielli on peanut milk characteristics and flavor. Nutr. Food Technol. Open Access, 2016;3(1).

6. Bakhtiar AH. Pengaruh cara dan lama penyimpanan dingin terhadap kandungan vitamin $\mathrm{c}$ dan aktivitas antioksidan cabai merah (Capsicum annum L.) [skripsi]. Malang: Universitas Islam Negri; 2009.

7. Rezaee KA, Sartipnia N, Babai Khalkhali M. Effect of storage temperatures on antioxidant capacity and bioactive compounds in raspberry fruit. International Journal of Plant, Animal and Environmental Sciences 4. 2014:343-9.

8. Galani JHY, Patel JS, Patel NJ, Talati JG. Storage of fruits and vegetables in refrigerator increases their phenolic acids but decreases the total phenolics, anthocyanis and vitamin $\mathrm{c}$ with subsequent loss of their antioxidant capacity. Antioxidants. 2017;6(59):1-19

9. Viswanad V, Aleykutty NA, Zacharia SM, Thomas L. Evaluation of antioxidant and free radical scavenging activity of samadera indica using in vitro models. Pharmacognosy Journal. 2011;3(23):85-90.

10. Aksoy L, Kolay E, Ağılönü Y, Aslan Z, Kargioğlu M. Free radical scavenging activity, total phenolic content, total antioxidant status, and total oxidant status of endemic Thermopsis turcica. Saudi Journal of Biological Sciences. 2013;20(3):235-9.

11. Hanada H. Phenolic antioxidant 2,6-di-tertbutyl-p-cresol (vitamin E synthetic analogue) 
does not inhibit 1,1'-dimetyl-4,4'-bipyridium dichloride (paraquat)-induced structural chromosomal damage in cultured leukocytes of the dark-spotted-frog Pelophylax (Rana) nigromaculatus. Hereditas. 2012;149(5):1737.

12. BHA and BHT: A Case for Fresh? [Internet] Scientific American. 2013; Dec 19. [cited 28 Febuari 2019]. Available from: https://www.scientificamerican.com/article/b ha-and-bht-a-case-for-fresh/

13. Jun M, Fu HY, Hong J, Wan X, Yang CS, Ho C-T. Comparison of antioxidant activities of isoflavones from kudzu root (Pueraria lobate ohwi). J of Food Science. 2010;2117-22.

14. Sumarlan S, Susilo B, Ahmad A, Mu'nim M. Ekstraksi senyawa antioksidan dari buah strawberry (Fragaria X Ananassa) dengan menggunakan metode microwave assisted extraction (kajian waktu ekstraksi dan rasio bahan dengan pelarut). Jurnal Keteknikan Pertanian Tropis dan Biosistem. 2019; 6:1.

15. Navghare VV, Dhawale SC, Phanse MA, Ingole1 PG, Pawale1 SS, Sonwane PP. Free radical scavenging property of some commonly known musa species. Indo American Journal of Pharmaceutical Research. 2013;3(8).
16. Park J, Lee M, Park E. Antioxidant activity of orange flesh and peel extracted with various solvent. Prev Nutr Food Sci. 2014;19:291-8.

17. Zahra ST. Uji aktivitas antioksidan dan formulasi sediaamn masker peel-off minyak daging buah alpukat (Persea Americana Mill) [skripsi]. Banda Aceh: Universitas Syaih Kuala; 2016.

18. Budiarti A, Kurnianingrum DAE. Pengaruh suhu dan lama penyimpanan terhadap kandungan vitamin $\mathrm{c}$ dalam cabai merah (Capsicum annuum. L) dan aktivitas antioksidannya. In: Anas Y, ed. Prosiding Seminar Nasional "Peluang Herbal Sebagai Alternative Medicine". Semarang: Fakultas Farmasi Universitas Wahid Hasyim. 2015:134-40.

19. Ozturk B, Celik SM, Karakaya M, Karakaya O, Islam A, Yarilgac T. Storage temperature affects phenolic content, antioxidant activity and fruit quality parameters of cherry laurel (Prunus laurocerasus L .). Journal of Food Processing and Preservation. 2017:1-10.

20. Tilahun S, Park DS, Taye AM, Jeong CS. Effects of storage duration on physicochemical and antioxidant properties of tomato (Lycopersicon esculentum Mill.). Horticultural Science \& Technology. 2016:88-97. 